\title{
Rights of Nature: Rivers That Can Stand in Court
}

\author{
Lidia Cano Pecharroman
}

AC4, Earth Institute, Columbia University, New York, NY 10027, USA; cano.lidia@columbia.edu; Tel.: +1-917-215-0178

Received: 7 December 2017; Accepted: 1 February 2018; Published: 14 February 2018

\begin{abstract}
An increasing number of court rulings and legislation worldwide are recognizing rights of nature to be protected and preserved. Recognizing these rights also entails the recognition that nature has the right to stand in court and to be represented for its defense. This is still an incipient field and every step taken in this direction constitutes a precedent from which to learn and on which to base new rulings and legislation initiatives. Within this doctrine, rivers seem to be on the spotlight and court rulings on the rights of rivers are the ones setting precedent. These cases have taken place in New Zealand, Ecuador, India, and Colombia. This review looks into what all these rulings and legislation worldwide say about the rights of nature and what legal and systemic considerations should be taken into account as the recognition of the rights of nature moves forward.
\end{abstract}

Keywords: rights; nature; rivers; Yamuna; Ganges; Atrato; Vilcabamba; Whanganui; jurisprudence; earth centric; deep ecology; law

\section{Introduction: The Rights of Nature-What, Why and How?}

Recognizing that nature has legal rights and accepting these rights as part of our legal systems require not only the introduction of new laws observing these rights, but also a shift in paradigm for them to be fit in a contemporaneous legal puzzle. Referring to a "shift" in paradigm and not the "introduction" of a newly created one is intentional, as the recognition of rights to nature has been already part of customary law for many indigenous populations around the world for centuries. These principles, however, have not been embedded in the development of modern environmental laws, grounded on an anthropocentric paradigm. This paradigm, has proven to be erroneous, as humans are irreversibly damaging the natural structures they depend on for survival despite the existence of environmental laws. The Paris Agreement and the planetary efforts that have been recently undertaken to move away from this approach and to develop in a sustainable manner point towards the possibility of a shift towards an earth-centered paradigm, where humans are part of the planetary system and aim at living in harmony with it. As mentioned before, the idea of making the rights of nature part of the way humans conceive their reality and rule their community is not new. Neither is the attempt to introduce this concept in modern legal systems. This essay reviews a suite of philosophical and practical efforts to recognize the rights of nature over the past 50 years, focusing on several recent cases involving rivers around the world.

The first scholar to raise the question of whether nature should be recognized the right to stand in court was Professor Christopher Stone, a professor from the University of Southern California who in 1972 wrote his famous essay: "Should Trees Have Standing? Toward Legal Rights for Natural Objects" [1]. To provide some background on the premises of Stone's essay, the Sierra Club had recently tried to sue Walt Disney Enterprises to prevent the construction of a ski resort in Mineral King Valley (in the Sierra Nevada Mountains). The US Court of Appeals in California responded, pointing out that the Sierra Club itself had not been injured by the project and as a result it did not possess the right to stand in court to bring a lawsuit against the corporation [2]. In response to the court's decision, Stone's essay expounded a robust set of reasons why the legal system should recognize nature's right to stand 
in court: to prevent cases like this in which neither environmental groups nor nature itself could be defended against damages in court. He introduces the topic by admitting that such a proposal might seem "frightening or laughable" as have any previous attempts to confer rights onto other entities in the past. A little more than a century ago, he argues, the majority of Americans were not outraged when a court would argue that Blacks were denied the rights of citizenship because they constituted "a subordinate and inferior class of beings, who had been subjugated by the dominant race" [3] or when another responded to a woman's willingness to become a lawyer that "the law of nature destines and qualifies the female sex for the bearing and nurture of the children [...] and all life-long callings of women, inconsistent with these radical and sacred duties of their sex, as is the profession of the law, are departures from the order of nature" [3]. These statements would sound outrageous if employed nowadays, but there was a time when they constituted legal jurisprudence. Women, slaves, or African Americans, were once rightless but as Stone reaffirms it is not "until the rightless thing receives its rights, [...that we can] see it as anything but a thing for the use of "us" - those who are holding rights at the time." [1] A similar argument is drawn by Steven Wise when providing reasons for why animals should also bear rights. He discusses that women, children, and slaves were once considered "legal things" and hence did not have the right to stand in court [4]. However, as our legislation evolves, in a similar fashion, animals with practical autonomy should too have rights. Furthermore, philosopher Peter Singer adds to this argument, arguing that, when recognizing more rights to humans than to animals in similar situations, we are being biased in favor of our own species (a phenomenon that he calls "speciesism") [5]. In the same manner, it is not until nature is recognized as holding certain rights that we will realize that nature is deserving of a chance to speak for itself.

Anticipating the counterargument that nature cannot stand in court as it is not a being, Stone and other scholars have a straightforward answer. Corporations, municipalities, and other entities have rights and can stand in court in the current legal system, so in the same way nature could be recognized certain rights and be represented in court. For those who counter that argument by noting that at least companies and governments can bear duties if asked for it in court, authors like Leimbacher reject the idea that there must exist a link between legal subjectivity and the ability to bear duties [6]. For instance, children have the right to be represented in court but do not bear any responsibility. Sitter goes further to clarify that legal subjectivity does not have to be linked to the idea to safeguard rights personally, as it is the case with nature.

Others may argue that there is not enough ground to justify the recognition of the rights of nature and that our legal systems were not designed for nature to be a holder of rights. But some authors have addressed these questions. Nedelsky, for instance, calls for the need for a new system to define rights. Rights should be defined in terms of relationships rather than the individuals that withhold said rights. As opposed to the idea that rights are a set of timeless and immutable values that already exist, instead rights constitute an intricate system of relationships that keep evolving. For instance, until recently, "great restrictions on the legal rights and opportunities for women were [in fact] believed to be consistent with a basic commitment to equality" [7]. The evolution of these relationships allows us to recognize new rights. These relationships do not only exist amongst humans but are also established when we interact with nature. As a result, we are able to recognize its rights as well as our duties towards it. Stone goes beyond this to define what it would mean for nature to be a "holder of legal rights" and establishes three requirements. First, the holder can institute legal actions on its behalf. Second, a court must take injury to it into account when granting redress. Third, this redress has to be to the benefit of it [1]. These definitions are nontrivial. They shed light on the basis for the rights of nature and the extension of these rights if applied.

Beyond the philosophical grounds for the rights of nature to stand in court, it is important to clarify what it means to hold these rights in legal terms. When venturing into such a debate, it is important to clarify the distinction between the legal institution of "personhood" and the implications of holding "locus standi." In the continental law tradition, holding legal personhood means holding a set of rights and duties. As individuals, every (physical) person holds legal personhood and has 
the rights and duties determined by the law. Similarly, a legal person, formed by a set of people or goods, holds legal personhood and is also given rights and duties by the law. Exercising these rights and duties would be the next step, but not every person holds legal competence to do so on its own. Some persons both physical and legal are deemed incapable of exercising such rights on their own. This could be due to their nature, as in the case of a company. It could also be a temporary situation, such as the case of children who will be able to fully exercise their rights and duties on their own once they become adults [8]. In both these cases, the full exercise of their rights takes place via a legal representative. Once a matter is brought to court, the parties interested in participating in the litigation process must demonstrate that the action challenged or the law put into question is affecting them directly or has some reasonable connection to their situation. The requirements and regulations in this regard vary across legal systems, but the overall idea is the same. To stand in court you need to hold legal personhood, be capable of exercising your rights, or have a legal representative otherwise, and hold locus standi.

So, where does nature fit into these definitions? As of today, there is no clear answer to this question. This discussion is currently being held worldwide in debates that courts, legislators, and international organizations are trying to settle. Many authors have called for a more flexible and inclusive theory for defining legal personhood that includes animals and nature. Some propose that the concept of legal personhood moves from a binary system [9] (holding or not legal personhood) to a system in which somebody or something can hold legal personhood to a certain degree [10]. In Korsgaard's words "for various, different, kinds of reasons, it seems inappropriate to categorize a fetus, a non-human animal, the environment, or an object of great beauty, as a person, but neither does it seem right to say of such things that they are to be valued only as means" [9]. Some authors have directly attributed the lack of flexibility in the way we define legal personhood to the fact that this concept "has long been associated with humanity, and even the paradigm of [...] corporations relies upon analogizing to humanity" [11]. Moving away from this paradigm would mean to "divorce the capacities-focused definition of legal personhood from the species-based definition of humanity" [11].

Finally, besides more theoretical approaches to whether rights of nature should and can be recognized by our legal systems, there is a more utilitarian approach to why these rights are needed to champion a protection of nature that has not been accomplished by the current legal system. Leimbacher argues that a relationship of dominance between humans and nature can never put a stop to further damaging nature [6]. The rights of nature from a utilitarian perspective are seen as a way to guarantee human's right to exist, as protecting nature, on which we depend, is a way to protect human interests. Leimbacher and other authors have linked the need to recognize the rights as a way to protect human rights to existence. Stone also explains that, because the health and well-being of humankind depend on the health of the environment, these goals will often be so mutually supportive that one can avoid deciding whether our rationale is to advance "us" or a new "us" that includes the environment. Other scholars such as Colon Ríos base the need to insert the rights of nature into our legal system on the theory of constituent power. Rights are the main tool to preserve conditions that are essential to the future exercise of rights by future generations. The environment will enable the development of future generations. Considering nature as a means for life has been a way to protect nature, protecting the right to a "healthful environment" and the human right to health [12]. In other words, we shall respect and protect the environment in which the next generations will flourish.

The legal and philosophical debates to define the rights of nature, how they should be applied, and the role they play in our current legal system is still open. However, some countries and international organizations are already including them in their legislations and debates at a national and international level.

\section{The Rights of Nature at a Local, National, and International Level}

Worldwide there is an increasing body of legislation, jurisprudence, and political declarations challenging the current paradigm and recognizing certain rights to nature. The process is still incipient 
and therefore it is important to examine the work that has already been done: first, to have a sense of where things stand and how far the rights of nature have permeated our society, second, to have a sense of how much work needs to be done in this realm, and third, to learn from the precedents when trying to include the rights of nature in new legislation. It is important to look both at local and national legislation, as well as the efforts carried out by the international community and the precedents set by indigenous populations that have embedded their entire legal systems in this paradigm for centuries.

The first place ever to recognize nature's right in an ordinance to protect the "citizens and environment [ ... ] general welfare" was the Tamaqua Borough (PA, USA) [13]. The ordinance sought to ban the dumping of toxic sewage sludge in the community as a violation of the rights of nature [12]. Indirectly, the regulation hints towards the recognition of nature rights by recognizing that "everyone has the right to a healthy, protected, and balanced environment" and the exercise of these rights must be granted to individuals, collectives, and to "other living things so they may develop in a normal and permanent way." Only two years later, the country that pioneered the inclusion of the rights of nature as a constitutional right was Ecuador. In 2008, they approved a new constitution with which the country aimed at "building a new way of coexistence amongst citizens, in diversity and harmony with nature" [14]. The constitution has a chapter [14] exclusively dedicated to the rights of nature. The text states that nature has the right to be respected, and that its existence and the maintenance and regeneration of its life cycles, structure, and evolving processes must be allowed for. Furthermore, it gives any person the right to ask public authorities to respect its rights. Moreover, the constitution states that the state will apply "precautionary" and "restrictive" measures to any activity that may lead to the extinction of a species, the destruction of the ecosystems, or the permanent alteration of natural cycles. These rights have already been used as a reference to interpret legislation in other matters. When a plaintiff asked the constitutional court to rule the Organic Law of Special Regime for the Conservation and Sustainable Development of the Province of Galapagos unconstitutional for prioritizing nature protection over Ecuadorians rights to internal migration, the Constitutional Court used the rights of nature to argue otherwise. The court ruled against the plaintiff highlighting, among other things, that the constitutional articles on the rights of nature are the basis for every person to demand from authority the fulfillment of said rights, as well as the encouragement and promotion of respect for the ecosystems [15], over internal migration rights in this case. The constitution is clear when it comes to proclaiming nature as an entity that holds rights (the right to be respected, to be taken care of, etc.). However, as constitutional principles remain broad, it is unclear how these rights would be exercised, and whether or when nature would hold locus standi to defend these rights. Only a year after Ecuador made such constitutional changes, Bolivia's constitution also included rights of nature as part of its new text: Section I: Environmental Rights (protection of environment) includes the following: "Article 33: Everyone has the right to a healthy, protected, and balanced environment. The exercise of this right must be granted to individuals and collectives of present and future generations, as well as to other living things, so they may develop in a normal and permanent way. Article 34: Any person, in his own right or on behalf of a collective, is authorized to take legal action in defense of environmental rights, without prejudice to the obligation of public institutions to act on their own in the face of attacks on the environment" [16]. In 2010, Bolivia approved the Law of the Rights of Mother Earth [14] and the Framework Law of Mother Earth and the Integral Development of Living Well (Ley 300 (2012), Ley Marco de la Madre Tierra y el Desarrollo Integral para Vivir Bien). The 2010 law created an Ombudsman for the Rights of Mother Earth (Defensoría de la Madre Tierra), an institution in charge of safeguarding the rights established in the law [17]. Moreover, the framework establishes a set of institutions that will take action if the rights of nature are violated. This entitles citizens to take legal action, as long as the government is not doing so first (Article 39 of Law 300 (2012), Framework Law of the Mother Earth and for the Integral Development for Living Well). Paradoxically, this law, even though it is dedicated to the establishment of the rights of nature, also states that people have rights to the exploitation of natural resources as long as permission is granted by the government. Unless these concepts are further developed legally, this approach continues to perpetuate the conventional legal 
approach where the exploitation of nature is allowed as long as it respects environmental regulations in place. Indigenous groups in the country have already expressed their disappointment at the lack of substance of the law [17]. The indigenous leaders of the Isiboro Sécure Indigenous Territory and National Park (Tipnis) recently presented a complaint before the International Court for the Rights of Nature against the Government of Evo Morales for the depredation of its territory [18].

In the international arena, this topic is gathering an increasing amount of attention. The efforts have focused on raising awareness on the topic and creating political resolutions to support the concept of the rights of nature, rather than getting closer to an actual definition of its legal meaning and implications. Nevertheless, these political declarations are an important first step towards the development of legislation at a national and local level. The General Assembly (GA) adopted its first resolution on Harmony with Nature in 2010, encouraging Member States to make use of the designated "Mother Earth Day" [19] and including Harmony with Nature as part of the Assembly's agenda on Sustainable Development. The Assembly, however, did not mention the concept of "rights of nature" per se until the following resolution in 2011 [20]; in the resolution, the GA, "Noting the first Peoples' World Conference on Climate Change and the Rights of Mother Earth," created an interactive dialogue to share national experiences on how to approach and measure sustainable development in harmony with nature [20]. These dialogues have been held annually on Mother Earth's Day (22 April) as a forum where scholars, civil society, and diplomatic representatives have discussed the concept of Harmony with Nature and the Rights of Nature. This constant activity and the interest of some countries to further deepen the concept of the rights of nature led the GA in its 2016 [20] resolution on Harmony with Nature to note that "some countries recognize the rights of nature in the context of the promotion of sustainable development, and express the conviction that, in order to achieve a just balance among the economic, social, and environmental needs of present and future generations, it is necessary to promote harmony with nature."

The rest of the international community has slowly followed through with this concept in the last three years. In 2014, the G77 [21] signed the letter "For a New World Order for Living Well," in which these countries recognized that "Earth and its ecosystems are our home." In the letter, "some countries recognize the rights of nature in the context of the promotion of sustainable development" and called for a holistic approach to development that may include the recognition of these rights to restore the integrity of the Earth's ecosystems. The International Union for Conservation of Nature (IUCN), for instance, seeks to move towards the recognition of the rights of nature. The IUCN Programme for 2017-2020 (approved in 2016) states that it "aims to secure the rights of nature and the vulnerable parts of society through strengthening governance and the rights-based approach to conservation." Doing so sets as part of its Target 6 to "raise awareness of the rights of nature, and the cultural and spiritual values of nature," and emphasizes the need to "include urban populations and youth in understanding nature's intrinsic and intangible values" and "to advance rights regimes related to the rights of nature" [22].

The existence of this legal and political precedence is sparking actions for the recognition of the rights of nature in other parts of the world, both on national and local levels. For instance, Mexico City recently approved its own constitutional text that recognizes citizens' rights to a healthy environment, determines that is the government's duty to protect nature, and establishes that "a secondary law will be issued to recognize and regulate the broader protection of the rights of nature conformed by all its ecosystems and species as a collective entity subject to rights" (See Article 13 of the Mexico City Constitution.). In Argentina, a senator has proposed a bill to recognize the rights of nature in the national legislation [23]. Similarly, in Brazil, a draft amendment has been presented whereby Sao Paolo "will promote the development of environmental policies, considering that members of nature have inherent rights to life and maintenance of their ecosystem processes" [24]. In Europe, a group of lawyers, environmentalists, and academics are organizing a so-called "European Citizens Initiatives" [25] to propose the adoption of a law that "recognizes the right of nature to exist, renew, and maintain its vital cycles" [26]. 
Finally, it would not be fair to talk about the legal doctrine of the rights of nature without mentioning the traditions and knowledge on this issue that indigenous populations have passed onto generations. The paradigm that embraces and understands nature as a being with rights has been part of many indigenous populations' worldviews for hundreds of years. Their interdependent relationship with nature has resulted in non-anthropocentric social systems in which human's harmonious relation with nature has been always the desirable outcome [27].

This view of the world is embodied by the Sumak Kawsay or living well, a prevalent way of life across Latin American indigenous populations. These communities see nature as the Pacha Mama, a being formed by the harmonious interactions of the beings and natural systems on Earth (Article 5.1. Law 300 (2012), Ley Marco de la Madre Tierra, Plurinational State of Bolivia). For some of them, Pacha Mama is considered a deity, the mother of humanity that humans should respect and take care of to continue living in harmony. The understanding of nature as the Pacha Mama is not only the idea of it as a deity, it is rather a philosophy of life [28]. It is a way of living in harmony with nature, co-existing with it, caring for it, and allowing for its regeneration to provide for the upcoming generations [29]. This conception of reality is part of the social fabric [30] and as a result it permeates all the norms that govern the way these communities live [31]. These deep ecology conceptualizations of life can be found in every corner of the world. For instance, the Maori in New Zealand express this reciprocal and equal relation between humans and nature with their saying "Ko au te awa, ko te awa ko au," which translates to "I am the river and the river is me" [32].

In the African continent, this philosophy of reciprocity and respect for nature is also ingrained in the traditions of indigenous populations that conceive nature as sacred and conceive the use of its resources as long as nature can regenerate. These societies contemplate within their norms the denomination of a custodian that takes care of the sacred territories and the development of livelihoods ingrained, dependent and respectful of nature. In 2015, the African Commission on Human and People's Rights, acknowledging the critical role of sacred sites and with the input of nature custodians, adopted resolution 372 [33] for the protection of sacred natural sites in the African continent [34]. In Asia as well there is a deep-rooted tradition amongst indigenous populations existing in almost every corner. The Asian Indigenous People's Pact as a representative of indigenous populations from 14 countries is committed to achieving the "integrity of the environment" and to "enhance the sustainable resource management systems of indigenous peoples." [35].

There are many examples of indigenous populations that regard nature with deep respect and have a strong sense of belonging to it. Much of the indigenous knowledge and livelihoods that have achieved harmony with nature match up with modern notions of nature conservation [36], and their effectiveness in being in balance with nature can be explained by modern science. Their knowledge and experience on how to promote the rights of nature is being heard in international forums and should be heard as part of the legislative process to include the rights of nature in our legislations.

\section{Can a River Stand in Court?}

Worldwide legal systems are gradually introducing the possibility of granting rights to nature to stand in court for protection. Examples of court rulings applying said legislation and recognizing rights to nature have started to emerge a little more than five years ago. These rulings have granted rights to rivers across the world in different terms. There is no explanation about why rulings have been more prevalent regarding the rights of rivers than those of other ecosystems. The first ruling recognizing the rights of nature was regarding a river, and the existence of this previous jurisprudence could have provided foundations for other judges to rule in the same way. The nature of rivers as a distinct mass of water elapsing across terrain with a quasi-permanent shape and presence may make it easier to legally define a river as an "object" that can become a "subject" with rights. To date, rivers have been recognized as holding rights by a court ruling in Ecuador, India, New Zealand, and Colombia. These cases are the first judicial attempts to apply legislation that recognizes the rights of nature or to set precedence in recognizing such rights. 
The first ruling was delivered in Vilcabamba, Ecuador. A public contractor started building a road next to the Vilcabamba River using dynamite and heavy machinery and depositing rocks and other construction materials in the river banks. The accumulation of these materials caused floods along the river and polluted the waters. After some affected citizens brought this case to the courts, the river's right to stand in court was admitted and those citizens representing the river continued in the process. The judge determined that the rights of nature had been violated-more specifically nature's right "to exist, to be maintained and to the regeneration of its vital cycles, structures and functions." This legal sentence did not stop the construction of the road, however. Instead the court ruled that the contractor should follow a set of environmental guidelines and recommendations that the Ministry of Environment had issued following a previous legal complaint against the road construction. It was then, on 30 March 2011 [37], that the rights of nature were recognized by a court for the first time. The ruling recognized the plaintiff's right to sue on the basis of Article 71 of the constitution, which establishes every citizen or nation's right to demand the authorities the compliance with the rights of nature. The ruling recognizes the rights of nature as a constitutional right to be observed and emphasizes that every citizen can defend such rights in court when violated. However, it does not further elaborate on when nature should hold locus standi per se. The court applies the precautionary principle deeming necessary to order the halt of any construction "until it is objectively demonstrated that there is no likelihood or danger" of environmental damage. Finally, to defend the construction works, the provincial governments alleged that respecting the rights of nature would mean the violation of the local's human right to development. To this allegation, the court responded that both rights are recognized by the constitution and should be pondered in the light of the constitutional principles. For this specific case, the court concluded that these rights are not colliding since the road can still be constructed while respecting nature's rights [38].

In New Zealand, members of the indigenous Maori tribes have disputed with the Crown the status of the Whanganui River for the last 140 years in the framework of the interpretation of the Treaty of Waitangi, a treaty declaring British Sovereignty in 1840 and defining Maori's land ownership, generally considered the founding document of New Zealand as a nation. Despite this, many Māori feel that the Crown did not fulfill its obligations under the Treaty and have presented evidence of this before sittings of the Waitangi Tribunal. In 2014, a settlement was finally reached [39] that would grant the river its own legal identity, with the rights, duties, and liabilities of a legal person. By this settlement, "the river becomes an entity in its own right, Te Awa Tupua" [39]. This settlement was turned into the Te Awa Tupua Act in 2017 by which the Whanganui becomes a legal person that will be able to be represented in court proceedings [40] and would have two guardians, one from the Crown and one from the Whanganui iwi [41] (see Part 2, Article 14, of the Te Awa Tupua 2017 Act: Te Awa Tupua is a legal person and has all the rights, powers, duties, and liabilities of a legal person). This has been so far the clearest legal reference to the way the rights of nature should be delineated and should be exercised. In this case, the Act, beyond declaring that nature has rights, explicitly grants legal personality to an entity within nature, i.e., the Whanganui River. It goes even further by naming those who should legally represent the river in court. The act makes a reference to the "Whanganui Iwi standing" (in Part 3, Subpart 2, named Ko au te Awa, ko te Awa ko au-Whanganui Iwi standing). It specifies that, for the purposes of the Resources Management 1991 Act, the trustees "are entitled to lodge submissions on a matter [...] affecting the Whanganui River" and are "recognized as having an interest [...] greater than any interest in common with the public generally." Given the novelty of this declaration, it will be a matter of time to see how these norms applied to practical matters.

Almost at the same time as the Te Awa Tupua Act was made official, the Uttrakhand High Court in India recognized that both the Ganges and its main tributary, the Yamuna, as well as "all their tributaries, streams, every natural water flowing with flow continuously or intermittently of these rivers" would be "legal and living entities having the status of a legal person with all corresponding rights, duties and liabilities" [42,43]. The case was brought to court when officials complained that the governments of Uttarakhand and Uttar Pradesh states were not cooperating with the federal 
government to set up a panel to protect river Ganges. The ruling [43] mentioned New Zealand's decision to recognize the Whanganui River as an ancestor and appointed legal custodians that would be the ones in charge of protecting the rivers (Paragraph 19 states: "The Director NAMAMI Gange, the Chief Secretary of the State of Uttarakhand and the Advocate General of the State of Uttarakhand are hereby declared persons in loco parentis as the human face to protect, conserve and preserve Rivers Ganga and Yamuna and their tributaries"). The court draws on the Supreme Court's jurisprudence regarding personhood for Hindu deities and reaffirms that Hindu deities as juridical persons are to be managed by those entrusted with the possession of their property. The court bases its decision on the need to protect the recognition and the faith of society given that both of these rivers "support and assist both the life and natural resources [...] of the community." The court regrettably did not elaborate on what the implications of such a declaration of rights would be, since the main focus of this ruling was actually on the nature of Indian federalism and the water management duties of federal and state governments and not on the rights of nature per se [44]. As aforementioned, three representatives are declared persons in loco parentis, as the persons in charge to protect the river. However, it is not discussed whether the river will hold locus standi whenever damaged or only under specific circumstances could these guardians defend the river's rights in court. This same court ruled in April of the same year that Himalayan glaciers Gangotri and Yamunotri are legal persons. However, the Indian Supreme Court later overturned both rulings [45] after the state of Uttrakhand argued that the ruling could lead to complicated legal situations given that the consequences of providing rights to these rivers were not clearly defined. The case has not been settled, as the petitioner intends to appeal [46], but it is reflective of many of the questions that are raised by those opposing the legal doctrine of the rights of nature. Uncertainty is certainly a challenge to overcome.

Also based on the need to protect the river from human activity was the Atrato River ruling in Colombia. Illegal mining activities near the Atrato River and its tributaries were polluting the river and damaging the livelihoods and health of those living in the area. Given the situation, the Center of Studies for Social Justice "Tierra Digna" [47] demanded the Government action to stop these activities and to protect the river. After this request was denied by the government, the case was brought to court. The judges noted the existence of a "serious violation of the fundamental rights to life, health, water, food security, the healthy environment, the culture and the territory of the ethnic communities that inhabit the Atrato River basin and its tributaries, attributable to the Colombian State entities." As a result, the court ordered that the river Atrato, its tributaries, and its basin have the right to be protected, preserved, and restored by the State and the communities. To safeguard these interests, the court mandates the government to appoint two representatives of the river, one would be a member of the community and the other a member of the government. Similarly, in this case, the river is provided with legal personhood and with representatives. However, when the river would have locus standi to be defended against any harm is unclear and has been left to be decided on a case-by-case basis.

The existence of this legal precedence is sparking actions for the recognition of the rights of nature in other parts of the planet. In fact, recently in September of 2017, Jason Flores-Williams (a lawyer in Denver) filed a suit in the Colorado Federal District Court seeking to hold the state of Colorado liable for the violation of the river's right to exist, flourish, and regenerate. The plaintiff in the suit is the river ecosystem, and, because the river itself cannot appear in court, Deep Green Resistance filed the suit as a "next friend" of the river (an individual who acts on behalf of another individual who does not have the legal capacity to act on his or her own behalf) [48]. The court has not ruled anything thus far but it is expected that similar cases will start sprouting all over the world. The movement supporting the rights of nature, and especially of rivers, to stand in court has found ground and encouragement on the existence of these precedents. Both the existence of political declarations and actual legislation make more plausible the idea of supporting the introduction of the rights of nature in other legal systems, and the existence of courts' rulings are setting a precedent by materializing the abstract idea of rights of nature into enforceable verdicts. 


\section{Conclusions and Challenges Moving Forward}

Introducing an earth-centered paradigm in our legal systems and providing nature with the right to stand in court is only the first step towards the actual integration and enforcement of the rights of nature. In this process, there are still roadblocks, dilemmas, and unresolved questions.

First, it is not yet clear what the legal implications and meaning of providing legal personhood to nature might be. The definition of legal personhood [49] varies across legal systems and it has even been an issue of dispute among academics as the rights, duties, and powers to be exercised by a legal person are not easily definable by the law. Critics of the doctrine of the rights of nature have expressed concern over the attribution of legal personhood to nature as a source of legal uncertainty. This uncertainty is even more accentuated when it comes to defining when nature holds locus standi and on what basis. The debate remains whether the traditional theories that define both legal personhood and locus standi need to become more flexible to adapt to new paradigms and the way society perceives animals and nature. There is still a great deal of confusion in this sense, even within the legal spheres. For example, the India Supreme Court suspended the court order that declared the Ganges and Yamuna rivers to be "legal persons," arguing that rivers cannot be considered as "living entities" [50]. However, being a "living entity" should not be the focus of the legal debate. Especially since our current legal theory and practice support a system where businesses and governments go to court on a daily basis even though they are not "living entities." While enough evidence could be provided both in favor and against the fact that ecosystems are living beings, this discussion should be held outside of the courts. Legally speaking, a unified argument that ecosystems can be provided legal personhood similar to the one provided to private entities and governments would overall contribute to a better and unified understanding of the objective of the rights of nature doctrine, providing nature with the right to stand in court. This process to redefine legal personhood should also include an attempt to define whether, and under which circumstances, nature holds locus standi. Revisiting the debates that human rights experts have held could offer a good start in the process, even though different legal system requirements will have to be taken into account. Finally, even if the meaning of both legal personhood and locus standi for nature are clarified, further cogitation and plausible arguments on the value added to providing rights to nature will be needed to foster the expansion of the rights of nature. For some, it is clear that the traditional environmental legislation approach, in which nature is a passive being protected by the law, is not working. From a deep ecology perspective, our current anthropocentric approach should be shifted to have the Earth at the center of the system if we want to achieve an actual sustainable future. However, the question still remains whether providing rights to nature is the way to go.

Second, once a ruling has recognized certain rights to nature, it must be complied with. However, the enforcement of the rulings has proved challenging given the lack of precedent and of compliance mechanisms to protect nature once its rights have been recognized. For instance, in Vilcabamba (Ecuador), even though the ruling recognized the rights of the river and condemned the local government to apply a set of mechanisms to protect the integrity of the river, the plaintiffs noted how the enforcement of the ruling proved very challenging after the legal victory. As a matter of fact, while the ruling arranged that the Provincial Government of Loja (Gobierno Provincial de Loja) would deliver a remediation plan within thirty days, many months passed before the plan was submitted to the Ministry of Environment for approval. Moreover, while the local government partially complied with the ruling, the plaintiffs complained that they had to pay for the execution of certain works that would protect their property and the river because the local government would not deliver on its duties [51]. In the case of the Atrato River, the ruling ordered the creation of a "Commission of Guardians of the Atrato River" within three months of the ruling (the commission should count on two designated guardians and an advising team with members from the Humboldt Institute and WWF Colombia, both organizations with prior experience in the protection of other rivers in Colombia). While the ruling is from November 2016, the panel was only recently formed in October of 2017 [52]. Other uncertainties regarding the meaning and enforcement of the ruling were brought up when 
the state of Uttrakhand brought the ruling to India's Supreme Court seeking, amongst other things, clarification on whether the newly appointed custodians of the rivers or the state government were liable to pay damages (declarations of the Highest court in the Himalayan state of Uttarakhand). Trying to prevent this problem, recent rulings such as the one on the Atrato River (Colombia) have attempted to provide a more detailed ruling to ease its enforcement. The ruling defined in detail the institutions that would be in charge of watching the ruling's compliance and diversify this task rather than giving it to one institution. In this case, the Attorney General would be in charge of it, with the support of the Communities, the Ombudsman, and the General Comptroller's Office [53]. Future court rulings and national legislation should follow these steps and define more carefully how the recognition of the rights of nature have to be enforced once recognized.

Third, if this legal approach was actually adopted, the question of how much should we give up in terms of development in order to respect the rights of nature remains. Several different philosophical approaches provide different answers to this question. According to the Sumak Kawsay or "living well" approach to development, we only need to develop enough to live well and in harmony with nature. This perspective challenges the current approach to development, associated with a perpetually increasing pattern of natural resource exploitation and growth. In an earth-centered paradigm, the rights of humans do not clash with the rights of nature because they have the same objective: to live in harmony. Therefore, if this paradigm was followed, the human approach to development would also shift. However, in practical terms, establishing the right balance between human development and the respect of nature's rights will prove challenging for the courts. Many fear that a shift in paradigm could lead to mountains or forests to sue over the depletion of their natural resources or the pollution of ecosystems and that this could stop the development of housing complexes, or roads, or other infrastructures. This process, however, already happens on a daily basis, when courts make decisions to allow or restrain corporations and governments' actions that affect a community. Nonetheless, we are still far from an ultimate answer in this regard.

So far, the governments of Bolivia [54] and Ecuador [55], which have strongly pushed for the declaration of the rights of nature at an international level, have adopted a very pragmatic approach within the country [56]. While their legal systems have adopted the rights of nature doctrine, these countries' extractive industries are blooming to the detriment of the ecosystems surrounding them. Social conflicts with the indigenous population attempting to protect nature in these areas are still prevalent, and there are ongoing debates on the tradeoffs of natural protection over resource extraction and the benefits of one or another at a national level. Nevertheless, the fact that, in these countries, the rights of nature are contained in their constitutions at least presents an opportunity to rethink and re-politicize the environmental debate [57].

All in all, the recognition of the rights of nature is still a very incipient movement within formal legal systems. It is a movement that brings along many uncertainties, but also the potential to fully develop and become the rule instead of the exception. When rethinking our current legal system and attempting to introduce an Earth-centric paradigm and its enforcement in court, these challenges should be kept in mind. History has proven that law often lags behind social change. As Leimbacher said, "legal standing for nature is nothing but a consequential continuation of a century-long process of expansion of the group of legal subjects." [6]. This is, arguably, the process that we are witnessing right now. The legal doctrine of the rights of nature is still being developed and changes in our paradigm are still underway. However, the rights of nature are here to stay. As the planet strives to achieve a more sustainable way of living, the rights of nature will offer a legal tool to regulate our relationship with nature from a different and more harmonious perspective. The court rulings, regulations, and political declarations discussed in this paper, even though still filled with uncertainties, play an important role in confirming and materializing the new values of deep ecology that are slowly growing within society. Legal uncertainties must be addressed by jurists, but reaching the right balance and building a robust system will only be reached through a trial and error process. What has been described in this review 
are the foundations over which we are building a new paradigm and the first steps towards a robust legal approach to recognizing the rights of nature, both in theory and in legal practice.

Acknowledgments: The author wrote this article under the sponsorship of the Fulbright program and Fundacion Ramon Areces. However, these sources did not cover the costs to publish in open access.

Conflicts of Interest: The authors declare no conflict of interest.

\section{References}

1. Stone, C.D. Should Trees Have Standing?-Towards Legal Rights for Natural Objects. South. Calif. Law Rev. 1972, 45, 450-501.

2. Neimark, P.; Mott, P.R. The Environmental Debate: A Documentary History, 2nd ed.; Grey House Publishing: Aminia, NY, USA, 2011; ISBN 1592376762.

3. Dred Scott, v. Sandford. 60 U.S. (19 How.) 396, 404-405 (1856). In Bailey v. Poindexter's Executor, 56 Va. (14 Gratt.) 132, 142-143 (1858), Superseded by Constitutional Amendment, U.S. Const. amend. XIV. Available online: https:/ / www.loc.gov/rr/program/bib/ourdocs/DredScott.html (accessed on 1 October 2017).

4. Wise, S. Animal rights, one step at a time. In Animal Rights: Current Debates and New Directions; Oxford Scholarship Press: Oxford, UK, 2005; p. 26.

5. Peter, S. Practical Ethics; Cambridge University Press: Cambridge, UK, 1979; Chapter 3; pp. 55-82, 151, ISBN 0521229200.

6. Leimbacher, H. Gender and Nature in Comparative Legal Cultures. In Comparing Legal Cultures; Nelken, D., Ed.; Routledge: New York, NY, USA, 2016; Chapter 8; p. 146. ISBN 9781855218987.

7. Nedelsky, J. Reconceiving Rights as Relationship (1993), Volume 1, Issue 1 (1993). Available online: https: // ssrn.com/abstract=2045687 (accessed on 11 February 2018).

8. Universidad Española a Distancia. Teoria del Derecho. Available online: http://ocw.innova.uned.es/ ocwuniversia/teoria-del-derecho/teoria-del-derecho/resumenes-1/tema-10-persona-y-personalidadjuridica-capacidad-juridica-y-capacidad-de-obrar (accessed on 7 January 2017).

9. Korsgaard, C.M. Personhood, Animals, and the Law; Cambridge University Press, 2013; Volume 12, pp. 25-32. Available online: https:/ /doi.org/10.1017/S1477175613000018 (accessed on 1 October 2017).

10. Kurki, V.A. Revisiting Legal Personhood. June/July 2016. Available online: http://www.uef.fi/documents/ 300201/0/Kurki++Revisiting+legal+personhood.pdf/56e99525-ba38-4c05-8034-3505d52d84a0 (accessed on 1 October 2017).

11. Dyschkant, A. Legal Personhood: How We Are Getting It Wrong. Illianois Law Review. Volume 2015, p. 2075. Available online: https:/ /illinoislawreview.org/wp-content/ilr-content/articles/2015/5/Dyschkant.pdf (accessed on 30 December 2017).

12. Brei, A.T. Rights \& Nature. J. Agric. Environ. Ethics 2013, 26, 393-408.

13. Tanasescu, M. Local, National, and International Rights of Nature. In Environment, Political Representation, and the Challenge of Rights; Palgrave Macmillan: London, UK, 2016; pp. 107-128. ISBN 978-1-349-55977-0.

14. Legal Text of the Ecuadorian Constitution of 2008. Available online: http:/ /www.asambleanacional.gob.ec/ sites/default/files/documents/old/constitucion_de_bolsillo.pdf (accessed on 22 October 2017).

15. Legal Text of the Bolivian Constitution of 2009. Available online: http://www.harmonywithnatureun.org/ content/documents/159Bolivia\%20Consitucion.pdf (accessed on 20 October 2017).

16. Ecuadorian Constitutional Court Ruling Number 017-12-SIN-CC Case Number 0033-10-IN. Available online: http:/ / doc.corteconstitucional.gob.ec:8080/alfresco/d/d/workspace/SpacesStore/cccd3c44-11af48bd-85f7-148c01ccfd36/0033-10-IN-sent.pdf?guest=true (accessed on 05 October 2017).

17. Bolivian Law 071, Ley de Derechos de la Madre Tierra, 21 December 2010. Available online: http:/ / www.harmonywithnatureun.org/content/documents/158Bolivia\%20Ley\%20071.pdf (accessed on 20 October 2017).

18. Barie, C.G. Nuevas Narrativas Constitucionales en Bolivia y Ecuador: El Buen Vivir y los Derechos de la Naturaleza. Latinoamérica. Revista de Estudios Latinoamericanos 2014, 59, 9-40. [CrossRef]

19. El Potosi. Denuncian a Evo ante el Tribunal de Derechos de la Naturaleza. 9 November 2017. Available online: http:/ / elpotosi.net/nacional/20171109_denuncian-a-evo-ante-el-tribunal-de-derechosde-la-naturaleza.html (accessed on 15 November 2017). 
20. General Assembly Resolution 63/278, International Mother Earth Day, A/RES/65/164, 15 March 2011. Available online: un.org/en/ga/president/65/initiatives/Harmony\%20with\%20Nature/A-RES-65-164.pdf (accessed on 1 October 2017).

21. General Assembly Resolution 07/208, Harmony with Nature, A/RES/70/208, 14 December 2012. Available online: un.org/ga/search/view_doc.asp?symbol=A/RES/70/208 (accessed on 1 October 2017).

22. General Assembly Resolution, Sustainable Development and Sustainable Development Goals, A/68/948, 7 July 2014. Available online: http:/ / www.g77.org/doc/A-68-948(E).pdf (accessed on 1 October 2017).

23. IUCN, Programme 2017-2020. September 2016. Target 6. Available online: https:/ / static1.squarespace.com/ static/55914fd1e4b01fb0b851a814/t/57f6894f440243a1628b3690/1475774800092/IUCN+Programme+ 2017-2020-FINAL+APPROVED.pdf (accessed on 20 November 2017).

24. Argentinian Senate. First Debate on the National Senate on the Rights of Nature. 7 July 2015. Available online: http:/ / www.senado.gov.ar/prensa/13264/noticias (accessed on 30 October 2017).

25. Municipal Chamber of Sao Paolo. Projeto de Emenda a Lei Organica 04-00005/2015 do Vereador Eduardo Tuma (PSDB). Available online: http:/ / cmspbdoc.inf.br/iah/fulltext/projeto/PLO0005-2015.pdf (accessed on 30 October 2017).

26. Mercado, J. Legal Recognition of the Sacredness of the Earth: Rights of Nature. Pachamama Alliance. 28 October 2015. Available online: https:/ / www.pachamama.org/blog/legal-recognition-of-the-sacrednessof-the-earth-rights-of-nature (accessed 30 October 2017).

27. Mumta Ito. ECI Project-A European Citizens Initiative for the Rights of Nature (Working Draft). Available online: https:/ / docs.google.com/document/d/1BywdKZXULM4eIkMv5BuIpksRjAjwMPKTCHJ10tRPoZw / pub (accessed on 1 October 2017).

28. Kiana, H. "Los Derechos de la Naturaleza: Las Filosofias Indigenas Estan Reformulando la Ley". Intercontinental Cry, January 2017. Available online: https://intercontinentalcry.org/es/los-derechosde-la-naturaleza-las-filosofias-indigenas-estan-reformulando-la-ley/ (accessed on 15 November 2017).

29. Zaffaroni, E.R. La Pacha Mama y el Humano. 2012. Available online: http://www.cuspide.com/Libro/ 9789505639250/La+Pachamama+Y+El+Humano (accessed on 11 February 2018).

30. Pachamama Alliance. Sumak Kawsay: Ancient Teachings of Indigenous Peoples. Available online: https: / / www.pachamama.org/sumak-kawsay (accessed on 20 November 2017).

31. Herold, K. The Rights of Nature: Indigenous Philosophies Reframing Law. Deep Green Resistance News Servic. Available online: https:/ / intercontinentalcry.org/rights-nature-indigenous-philosophies-reframinglaw / (accessed on 20 October 2017).

32. Rubiano, M.P. "Si los Bosques Siguen en Pie es por Nosotros": Indígenas en la Cumbre del Cambio Climático. El Espectador. 15 November 2017. Available online: https:/ / www.elespectador.com/noticias/ medio-ambiente/si-los-bosques-siguen-en-pie-es-por-nosotros-indigenas-articulo-723281 (accessed on 20 November 2017).

33. Afican Commission on Human and People's Rights. ACHPR/Res 372 (LX) 2017. Resolution on the Protection of Sacred Natural Sites and Territories. Available online: http:/ /www.achpr.org/sessions/60th/resolutions/ 372/ (accessed on 10 November 2017).

34. Wilton, F. Respect Sacred Natural Sites to Guarantee Human Rights, Says New African Commission Resolution. IUCN, 11 October 2017. Available online: https://www.iucn.org/news/commission-environmentaleconomic-and-social-policy /201710/respect-sacred-natural-sites-guarantee-human-rights-says-new-africancommission-resolution (accessed on 20 October 2017).

35. Verschuren, B.; Wild, R.; McNeely, J.; Oviedo, G. Sacred Natural Sites, Conserving Nature and Culture; Earthscan: London, UK; Washington, DC, USA, 2010; p. 22. ISBN 978-1-84971-166-1.

36. Asia Inigenous Pact Mission and Vision. Asia Indigenous Pact Official Website. Available online: https: / / aippnet.org/about-us / (accessed on 30 October 2017). 
37. UNEP. Indigenous People and Nature: A Tradition of Conservation. 26 April 2017. Available online: http:/ / web.unep.org/stories/story/indigenous-people-and-nature-tradition-conservation (accessed on 20 October 2017).

38. Ruling by the Ecuadorian Sala Penal de la Corte Provincial. Protection Action. Ruling Number No. 11121-2011-0010. Casillero N0. 826. 30 March 2011. Available online: http:/ / consultas.funcionjudicial.gob. ec/informacionjudicial/public/informacion.jsf (accessed on 10 October 2017).

39. El Correo. Jurisprudencia Ecuatoriana sobre Derechos de la Naturaleza. 8 June 2011. Available online: http:/ / www.elcorreo.eu.org/IMG/article_PDF/Jurisprudencia-Ecuatoriana-sobre-Derechos-dela-Naturaleza_a20229.pdf (accessed on 10 October 2017).

40. Williams, J. Te Awa Tupua. Kokiri: Raumati, 2016; pp. 28-31. Available online: https://www.tpk.govt.nz/ en/mo-te-puni-kokiri/kokiri-magazine/kokiri-33-2016/te-awa-tupua (accessed on 20 October 2017).

41. Davison, I. Whanganui River Given Status of a Person under Unique Treaty of Waitang Settlement. New Zealand Herald, 15 March 2017. Available online: http:/ / www.nzherald.co.nz/nz/news/article.cfm?c_ $\mathrm{id}=1 \&$ objectid=11818858 (accessed on 10 October 2017).

42. Roy, E.A. New Zealand River Granted Same Legal Rights as Human Being. The Guardian, 16 March 2017. https:/ / www.theguardian.com/world/2017/mar/16/new-zealand-river-granted-same-legal-rights-as-human-being (accessed on 10 October 2017).

43. Safi, M. Ganges and Yamuna Rivers Granted Same Legal Rights as Human Beings. The Guardian, 21 March 2017. Available online: https:/ / www.theguardian.com/world/2017/mar/21/ganges-and-yamuna-rivers-grantedsame-legal-rights-as-human-beings (accessed on 30 December 2017).

44. Mohd, S.V. State of Uttarkhand and Others (Writ Petition (PIL) No. 126 of 2014. 20 March 2017. Available online: http:/ / lobis.nic.in/ddir/uhc/RS/orders/22-03-2017/RS20032017WPPIL1262014.pdf (accessed on 30 December 2017). Paragraph 19.

45. Vrinda, N. Indian Court Recognizes Rivers as Legal Entities. ICONnect, International Journal of Constitutional Law Blog. Available online: http://www.iconnectblog.com/2017/06/indian-courtrecognizes-rivers-as-legal-entities / (accessed on 10 October 2017).

46. BBC. India's Ganges and Yamuna Rivers Are 'Not Living Entities'. 7 July 2017. Available online: http: / / www.bbc.com/news/world-asia-india-40537701 (accessed on 30 October 2017).

47. RTE. Indian Supreme Court Rules Rivers Are Not People. 7 July 2017. Available online: https:/ / www.rte.ie/ news /2017/0707/888557-india-rivers / (accessed on 30 October 2017).

48. Colombia Constitutional Court Ruling T-622 of 2016, Expediente T-5.016.242. Available online: https: / /justiciaambientalcolombia.org/2017/05/07/sentencia-rio-atrato/ (accessed on 20 November 2017).

49. Turkewitz, J. Corporations Have Rights, Why Shouldn't Rivers. The New York Times, 26 September 2017. Available online: https://www.nytimes.com/2017/09/26/us/does-the-colorado-river-have-rights-alawsuit-seeks-to-declare-it-a-person.html?_r=0 (accessed on 20 November 2017).

50. Quintana Adriano, E. Natural Persons, Juridical Persons and Legal Personhood. Mex. Law Rev. 2015, 8, 101-118. [CrossRef]

51. The Times of India. Supreme Court Stays Uttarakhand High Court's Order Declaring Ganga and Yamuna 'Living Entities'. 7 July 2017. Available online: https://timesofindia.indiatimes.com/india/supremecourt-stays-uttarakhand-high-courts-order-declaring-ganga-and-yamuna-living-entities / articleshow / 59489783.cms (accessed on 30 November 2017).

52. Suarez, S. Defendiendo la Naturaleza: Retos y Obstáculos en la Implementación de los Derechos de la Naturaleza Caso río Vilcabamba. FES Energia y Clima 2013. Available online: http:/ /library.fes.de/pdffiles/bueros/quito/10230.pdf (accessed on 10 October 2017).

53. Colombia Attorney General Bulletin 829. 15 October 2017. Available online: https://www.procuraduria.gov.co/ portal/Procuraduria-integra-panel-de-expertos-para-proteger-rio-Atrato.news (accessed on 20 October 2017).

54. Tierra, D. Todas y Todos Somos Guardianes del Atrato. Available online: http://tierradigna.org/pdfs / SomosGuardianesDelAtrato.pdf (accessed on 30 October 2017).

55. Schilling-Vacaflor, A. Contestations over Indigenous Participation in Bolivia's Extractive Industry: Ideology, Practices, and Legal Norms; GIGA (Working Paper), No. 254, September 2014; GIGA German Institute of Global and Area Studies: Hamburg, Germany, 2014. 
56. Steven, C.; Winterbottom, R.; Reytar, K.; Strong, A. Ecuador Shows Why Communities and the Climate Need Strong Forest Rights. World Resources Institute, 19 September 2014. Available online: http: / www.wri. org/blog/2014/09/ecuador-shows-why-communities-and-climate-need-strong-forest-rights (accessed on 20 November 2017).

57. Lalander, R. Rights of Nature and the Indigenous Peoples in Bolivia and Ecuador: A Straitjacket for Progressive Development Politics? Iberoam. J. Dev. Stud. 2014, 3, 148-172. 